\title{
Perbedaan Reaksi Pasar terhadap Pelantikan Presiden dan Wakil Presiden Negara Indonesia Tahun 2019
}

\author{
Gede Paramartha Daisuke Matsuzawa1 \\ Fakultas Ekonomi dan Bisnis \\ Universitas Udayana, Indonesia
}

\author{
Maria Mediatrix Ratna Sari ${ }^{2}$ \\ Fakultas Ekonomi dan Bisnis \\ Universitas Udayana, Indonesia
}

Surel : paramarthadaisuke@yahoo.com

\section{ABSTRAK}

Penelitian ini merupakan event study yang bertujuan untuk mengetahui reaksi pasar yang ditimbulkan dari peristiwa pelantikkan presiden dan wakil Presiden Indonesia tahun 2019, terhadap perusahaan yang terdaftar di sektor saham LQ45 pada tanggal 20 Oktober 2019, dengan menggunakan indikator abnormal return. Uji statistik yang digunakan untuk menguji hipotesis adalah uji statistik deskriptif, uji normalitas dan uji paired sample t-test. Hasil dari paired sample t-test pada abnormal return adalah tidak ada perbedaan yang signifikan, yang artinya pasar tidak merespon peristiwa tersebut. Hasil tersebut menunjukan bahwa pasar efisien tidak terjawab pada peristiwa pelantikkan presiden dan wakil presiden Indonesia tahun 2019 karena tidak adanya abnormal return di dalamnya.

Kata Kunci: $\quad$ Event Study; Reaksi Pasar; Abnormal Return; Pelantikkan Presiden 2019.

\section{Differences in Market Reactions to the Inauguration of the President and Vice President of the Indonesian State in 2019}

\section{ABSTRACT}

This research is an event study that aims to determine the market reaction arising from the inauguration of the president and vice president of Indonesia in 2019, against companies listed in the LQ45 stock sector on October 20,2019, using the abnormal return indicator. Statistical tests used to test hypotheses are descriptive statistical tests, normality tests and paired sample $t$-test. The result of paired sample $t$ test on abnormal return is that there is no significant difference, which means the market does not respond to the event. These results indicate that the efficient market is not answered in the event of inducting the president and vice president of Indonesia in 2019 due to the absence of abnormal returns in it.

Keywords: $\quad$ Event Study; Market Reaction; Abnormal Return; President Election 2019.

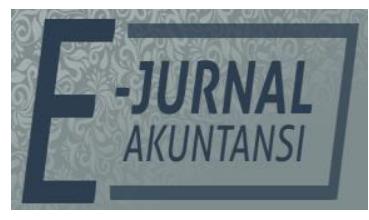

e-ISSN 2302-8556

Vol. 30 No. 10

Denpasar, Oktober 2020

Hal. 2514-2524

DOI:

10.24843/EJA.2020.v30.i10.p06

PENGUTIPAN:

Matsuzawa, G. P. D. \& Sari,

M. M. R. (2020). Perbedaan Reaksi Pasar terhadap

Pelantikan Presiden dan Wakil Presiden Negara Indonesia Tahun 2019. EJurnal Akuntansi, 30(10), 2514-2524

RIWAYAT ARTIKEL: Artikel Masuk: 26 Februari 2020 Artikel Diterima: 8 Juli 2020

Artikel dapat diakses : https://ojs.unud.ac.id/index.php/Akuntansi/index 


\section{PENDAHULUAN}

Pasar modal adalah tempat bagi investor yang ingin memanfaatkan sejumlah dana miliknya untuk memperoleh keuntungan melalui suatu risiko tersendiri. Pasar modal akan efisien bila harga instrumen keuangan yang diperjual-belikan memperlihatkan secara akurat nilai perusahaan termasuk prospek laba dan kualitas manajemennya. Pasar modal juga memiliki peranan penting bagi perekonomian suatu negara, Semakin berkembang pasar modal di suatu negara akan mempercepat pertumbuhan ekonomi di negara tersebut. (Yusuf \& Hidayah, 2014) menyatakan pasar modal memiliki dua fungsi utama, yaitu fungsi ekonomi dan fungsi keuangan. Fungsi ekonomi pasar modal adalah sebagai sarana untuk mempertemukan pihak yang kelebihan dana (investor) dengan pihak yang membutuhkan dana (issuer). Fungsi keuangan pasar modal adalah memberi kesempatan kepada investor untuk memperoleh return (keuntungan) sesuai dengan karakteristik investasi yang dipilih.

Informasi merupakan hal yang sangat penting dalam pasar modal. Informasi seringkali tidak disepelekan oleh para investor, hal ini biasanya dapat tercermin dari aktivitas jual beli dan harga saham atas suatu informasi atau peristiwa tertentu karena ini investor dapat bereaksi atas suatu informasi atau peristiwa yang dianggapnya bernilai. Informasi sendiri dibagi menjadi dua yaitu informasi internal dan informasi eksternal. Informasi internal merupakan informasi atas peristiwa yang terjadi di dalam perusahaan misalnya kebijakan dividen, kebijakan ekspansi, dan berbagai kebijakan internal perusahaan. Informasi eksternal merupakan informasi atas peristiwa yang terjadi diluar kebijakan yang dibuat oleh perusahaan.

Keputusan investor yang dilakukan oleh investor merupakan reaksi atas informasi yang mereka terima atau suatu peristiwa yang terjadi, dimana peristiwa tersebut mampu mempengaruhi keputusan mereka dalam berinvestasi. Informasi yang dipublikasikan sebagai suatu pengumuman akan memberikan sinyal bagi investor dalam pengambilan keputusan investasi. Para pelaku pasar sebaiknya terlebih dahulu menginprestasikan dan menganalisis suatu informasi sebagai sinyal baik atau sinyal buruk ketika informasi tersebutu diumumkan dan semua pelaku menerima informasi tersebut. Jika pengumuman tersebut mengandung nilai positif, maka diharapkan pasar akan bereaksi pada waktu pengumuman tersebut diterima oleh pasar.

Saham adalah dokumen berharga yang menunjukkan bagian kepemilikan atas suatu perusahaan. Dengan kata lain, ketika seseorang membeli saham maka orang tersebut telah membeli sebagian kepemilikan atas perusahaan tersebut. Saham dibedakan menjadi dua jenis yaitu saham biasa (common stock) dan saham preferen (preferred stock). Saham biasa adalah saham yang dapat diklaim berdasarkan profit dan loss yang terjadi pada suatu perusahaan. Jika dilakukan likuidasi, maka pemegang saham biasa akan menjadi prioritas terakhir dalam pembagian dividen dari penjualan aset perusahaan. Sedangkan saham preferen adalah saham dimana pembagian labanya tetap, dan ketika perusahaan mengalami kerugian maka pemegang saham preferen akan diberikan prioritas utama dalam bagi hasil penjualan aset.

Tanggal 20 Oktober 2019, pelantikan Presiden dan Wakil Presiden Indonesia periode 2019-2024 telah resmi dilaksanakan. Presiden dengan atas 
nama Ir.H. Joko Widodo dan Wakil Presiden dengan atas nama Dr.(HC) KH.Ma'ruf Amin. Pasangan Presiden dan Wakil Presiden ini dilantik dengan atas dasar kemenangan dalam pemilihan umum presiden dan wakil presiden yang terjadi pada tanggal 17 April 2019. Pasangan Jokowi-Ma'ruf menang telak atas pasangan Prabowo-Sandiaga dengan selisih suara sebesar 16.957.123 suara, pasangan Jokowi-Ma'ruf mendapatkan suara sebanyak 85.607.362 suara atau 55,50 persen dari total suara sah nasional. Sedangankan pasangan PrabowoSandiaga mendapatkan suara 68.650.239 suara atau 44,50 persen dari total suara sah nasional. Ir. H. Joko Widodo sebelumnya sudah menjabat sebagai Presiden Indonesia pada periode tahun 2014-2019, dengan pasang Wakil Presiden Drs. H. Muhammad Jusuf Kalla.

Acara pelantikan Presiden Joko Widodo dan Wakil Presiden Ma'ruf Amin yang digelar di Gedung DPR/MPR, Jakarta pada hari minggu tanggal 20 Oktober 2019. Acara ini menandai secara resmi dimulainya masa jabatan kedua dan terakhir Joko Widodo sebagai Presiden dan masa jabatan pertama Ma'ruf Amin sebagai Wakil Presiden Indonesia. Kemenangan pasangan ini dalam pemilihan umum presiden sempat digugat oleh Badan Pemenangan Nasional Prabowo Subianto-Sandiaga Uno ke Mahkamah Konstitusi, namun akhirnya ditolak. Berdasarkan penolakan Mahkamah, Komisi Pemilihan Umum kemudian secara resmi menetapkan Jokowi-Ma'aruf Amin sebagai pemenag.

Sehubungan dengan peristiwa pelantikan Presiden dan Wakil Presiden pada tanggal 20 Oktober 2019, indeks IHSG menunjukkan adanya kecenderungan kenaikan harga saham, sehingga penelitian ini dilakukan untuk memastikan apakah ada atau tidaknya reaksi pasar terhadap pelantikan Presiden dan Wakil Presiden Indonesia tahun 2019 dengan menggunakan event study.

Studi peristiwa (event study) merupakan studi yang mempelajari reaksi pasar terhadap suatu peristiwa (event) yang informasinya dipublikasikan sebagai suatu pengumuman. Reaksi pasar ditunjukkan dengan adanya perubahan harga dan volume perdagangan dari sekuritas bersangkutan (Hartono, 2017:264). Abnormal return atau excess return merupakan kelebihan dari return yang sesungguhnya terjadi terhadap return normal. Suatu pengumuman menimbulkan reaksi pasar akan memberikan abnormal return kepada pasar, dan begitu sebaliknya.

Terdapat beberapa penelitian sebelumnya yang meneliti reaksi pasar terhadap informasi eksternal berupa regulasi baru yang dikeluarkan oleh pemerintah, kesepakatan atau kerja sama yang dibuat pemerintah, pemilihan umum presiden maupun peristiwa lainnya yang dapat berpengaruh terhadap tingkat kestabilan kondisi perekonomian pada suatu negara. (Ayu \& Prameswari, 2018) meneliti mengenai reaksi pasar modal Indonesia terhadap peristiwa pemilihan Gubernur DKI Jakarta tahun 2017 mendapatkan hasil penelitian ini memberikan hasil tidak terdapat perbedaan rata-rata abnormal return dan trading volume activity sebelum dan sesudah Pemilihan Gubernur DKI Jakarta Tahun 2017. (Pastika \& Widanaputra, 2019) dalam penelitiannya menemukan bahwa pengumuman dividen saham tidak berpengaruh terhadap abnormal return, hal ini dibuktikan dengan hasil uji paired sample test dengan tingkat signifikansi $0,455(0,455>0,05)$ yang berarti tidak terdapat perbedaan ratarata abnormal return yang signifikan antara sebelum dan sesudah pengumuman 
dividen saham. (Firstiany \& Wirama, 2019) menunjukkan hasil pengujian one sample t-test menunjukkan bahwa pasar tidak bereaksi atas pengumuman right issue.

Sementara itu, (Napitupulu \& Yasa, 2018) menyatakan bahwa terdapat abnormal return terhadap perubahan peraturan Kemenperin NOMOR 31/MIND/PER/8/2017 pada perusahaan manufaktur pada hari ketiga sebelum pengumuman perubahan peraturan dan hari kedua setelah pengumuman perubahan peraturan. Hasil penelitian tersebut juga sejalan dengan penelitian (Wahyudhi \& Suaryana, 2019) terdapat reaksi negatif pasar modal atas pengumuman kesepakatan investasi bidang infrastruktur dalam pertemuan tahunan IMF-World Bank 2018. Xiao \& Gao et al. (2017) meneliti tentang dampak perubahan peraturan pada industri makanan kasus hukum keamanan pangan China menghasilkan cumulative abnormal return yang signifikan. (Ketut \& Ulupui, 2013) Hasil pengujian hipotesis pertama secara statistik menunjukkan bahwa terdapat reaksi pasar positif di sekitar peristiwa pengumuman ESOP. Pengujian hipotesis kedua menunjukkan bahwa pengumuman nilai opsi saham dalam ESOP berpengaruh positif terhadap abnormal return di Bursa Efek Indonesia.

Adanya ketidakkonsistenan hasil dalam beberapa penelitian tersebut, maka reaksi pasar terhadap pemberlakuan peraturan atau regulasi baru dan peristiwa di luar perusahaan semakin menarik untuk diteliti. Penelitian ini menguji reaksi pasar terhadap peristiwa pelantikan presiden dan wakil presiden Indonesia tahun 2019.

Konsep efisiensi pasar membahas bagaimana pasar merespons informasiinformasi yang masuk, dan bagaimana informasi tersebut selanjutnya bisa mempengaruhi pergerakan harga sekuritas menuju harga keseimbangan yang baru (Tandelilin, 2010:218). Menurut hipotesis pasar yang efisien (EMH), harga aset (dalam hal ini harga saham) mencerminkan datangnya informasi baru tentang peraturan dengan cepat. Perusahaan yang mendapat keuntungan dari suatu regulasi dapat menghasilkan abnormal return yang positif, perusahaan yang dirugikan oleh peraturan diharapkan menghasilkan abnormal return negatif (Rao \& Goldsby, 2009). Ang (1997) menyebutkan konsep efisiensi pasar yaitu investor selalu menyertakan faktor informasi yang tersedia kedalam keputusan mereka sehingga terefleksi pada harga yang mereka transaksikan, sehingga harga yang berlaku di pasar telah mengandung informasi tersebut.

Pengujian kandungan informasi dimaksudkan untuk melihat reaksi pasar dari suatu pengumuman (Hartono, 2017:585). Apabila pasar bereaksi terhadap informasi yang diumumkan atau dipublikasikan berarti informasi tersebut mengandung nilai ekonomis. Indikator untuk mengukur adanya reaksi pasar dapat dilihat dari abnormal return yang diperoleh investor, sehingga apabila terdapat abnormal return di sekitar peristiwa pengumuman atau penetapan kebijakan menandakan bahwa pasar bereaksi dengan cepat terhadap informasi tersebut. Hal itu juga menandakan, bahwa pasar adalah pasar yang efisien bentuk setengah kuat.

Hipotesis ini didukung oleh beberapa penelitian sebelumnya yang meneliti mengenai reaksi pasar terhadap peristiwa non ekonomi. (Napitupulu \& Yasa, 2018) menyatakan bahwa terdapat abnormal return terhadap perubahan peraturan Kemenperin NOMOR 31/M-IND/PER/8/2017 pada perusahaan 
manufaktur pada hari ketiga sebelum pengumuman perubahan peraturan dan hari kedua setelah pengumuman perubahan peraturan. Hasil penelitian tersebut juga sejalan dengan penelitian (Wahyudhi \& Suaryana, 2019) terdapat reaksi negatif pasar modal atas pengumuman kesepakatan investasi bidang infrastruktur dalam pertemuan tahunan IMF-World Bank 2018. Xiao \& Gao et al. (2017) meneliti tentang dampak perubahan peraturan pada industri makanan kasus hukum keamanan pangan China menghasilkan cumulative abnormal return yang signifikan. (Ketut \& Ulupui, 2013) Hasil pengujian hipotesis pertama secara statistik menunjukkan bahwa terdapat reaksi pasar positif di sekitar peristiwa pengumuman ESOP. Pengujian hipotesis kedua menunjukkan bahwa pengumuman nilai opsi saham dalam ESOP berpengaruh positif terhadap abnormal return di Bursa Efek Indonesia. Utami et al. (2017) menyatakan bahwa terdapat perbedaan yang signifikan abnormal return sebelum dan sesudah peristiwa penguatan tertinggi kurs dolar AS terhadap nilai tukar rupiah.

$\mathrm{H}_{1}$ : Terdapat perbedaan reaksi pasar sebelum dan sesudah peristiwa pelantikan presiden dan wakil presiden Indonesia tahun pada tanggal 20 Oktober 2019.

\section{METODE PENELITIAN}

Penelitian ini mengasumsikan pasar modal Indonesia sudah efisien dalam bentuk setengah kuat, ini dikarenakan pasar modal Indonesia masih berkembang. Penelitian ini menggunakan metode periode pendek (short event window) selama 6 hari yang terdiri dari 3 hari sebelum Pelantikan Presiden dan Wakil Presiden Indonesia Tahun 2019 dilaksanakan (t-3), 1 hari saat pelaksanaan Pelantikan Presiden dan Wakil Presiden Indonesia 2019 (t0), dan 3 hari sesudah Pelantikan Presiden dan Wakil Presiden Indonesia 2019 dilaksanakan (t+3). Peneliti menilai dengan menggunakan 6 hari merupakan jumlah yang tepat untuk mengetahui respon dari para investor atas kejadian pengumuman suatu peristiwa. Tanggal peristiwa (event date) pada penelitian ini adalah pada tanggal 20 Oktober 2019. Oleh karena itu, penelitian ini menetapkan tanggal peristiwa pada tanggal 20 Oktober 2019.

Lokasi penelitian ini dilakukan di Bursa Efek Indonesia (BEI) pada indeks saham LQ45 dengan mengakses www.idx.co.id, yang merupakan website resmi dari Bursa Efek Indonesia. Alasan penelitian ini menggunakan indek saham LQ45, karena sahamnya memiliki karakteristik dengan tingkat likuiditas tinggi sehingga mudah untuk diperdagangkan dan memiliki kapitalisasi pasar di BEI yang relatif besar. Adapun obyek penelitian ini yaitu abnormal return di sekitar tanggal Pelantikan Presiden dan Wakil Presiden Indonesia Tahun 2019.

Variabel dependen dalam penelitian ini adalah abnormal return. Abnormal return adalah kelebihan dari return yang sesungguhnya terjadi terhadap return ekspektasian (return yang diharapkan oleh investor). Maka return tak normal (abnormal return) adalah selisih antara return sesungguhnya yang terjadi dengan return ekspektasian (Hartono, 2015:647). Langkah-langkah untuk mengukur abnormal return, yaitu sebagai berikut:

$$
\mathrm{R}_{\mathrm{j}, \mathrm{t}}=\frac{P_{i, t^{-}} P_{i, t-1}}{P_{i, t-1}}
$$

Keterangan:

$$
\mathrm{R}_{\mathrm{j}, \mathrm{t}} \quad=\text { return saham i pada periode ke-t }
$$


$\mathrm{P}_{\mathrm{j}, \mathrm{t}} \quad$ = harga saham penutupan perusahaan $\mathrm{i}$ pada periode ke-t

$\mathrm{P}_{\mathrm{i}, \mathrm{t}-1} \quad=$ harga saham penutupan perusahaan i pada periode ke-t1

Return ekspektasian merupakan return yang harus diestimasi. Mengestimasi return ekspektasian dalam penelitian ini menggunakan model market-adjusted model karena model ini beranggapan bahwa penduga yang terbaik untuk mengestimasi return suatu sekuritas adalah return indeks pasar pada saat tersebut. Dengan menggunakan model ini, maka tidak perlu menggunakan periode estimasi untuk membentuk model estimasi, karena return sekuritas yang diestimasi adalah sama dengan return indeks pasar. Langkahlangkah untuk mengukur return ekspektasian adalah sebagai berikut:

$\mathrm{E}\left[\mathrm{R}_{\mathrm{i}, \mathrm{t}}\right]=\mathrm{R}_{\mathrm{mt}}$

Keterangan:

$\mathrm{E}\left[\mathrm{R}_{\mathrm{i}, \mathrm{t}}\right]=$ return ekspektasian sekuritas ke-i pada periode peristiwa ke-t

$\mathrm{R}_{\mathrm{mt}} \quad=$ return pasar pada periode $\mathrm{t}$

Perhitungan return pasar dalam penelitian ini menggunakan data sektor saham infrastruktur sebagai return pasar. Return pasar diperoleh dengan rumus sebagai berikut.

$$
\mathrm{R}_{\mathrm{m}, \mathrm{t}}=\frac{I H S G_{t}-I H S G_{t-1}}{I H S G_{t}}
$$

Keterangan:

$R_{m, t} \quad=$ Return indeks pasar pada hari ke $-\mathrm{t}$

$I_{H S G} \quad=$ Indeks harga saham gabungan penutupan pada hari ke $-\mathrm{t}$

$I H S G_{t-1} \quad=$ Indeks harga saham gabungan penutupan pada hari ke t-1

Abnormal return adalah selisih antara return sesungguhnya yang terjadi dengan return ekspektasian yang dirumuskan sebagai berikut.

$\mathrm{RTN}_{\mathrm{i}, \mathrm{t}}=\mathrm{R}_{\mathrm{i}, \mathrm{t}}-\mathrm{E}\left[\mathrm{R}_{\mathrm{i}, \mathrm{t}}\right]$

Keterangan:

$\mathrm{RTN}_{\mathrm{i}, \mathrm{t}}=$ return tak normal (abnormal return) sekuritas ke-i pada periode peristiwa ke-t

$\mathrm{R}_{\mathrm{i}, \mathrm{t}}=$ return realisasian yang terjadi untuk sekuritas ke-i pada periode peristiwa ke-t

$\mathrm{E}\left[\mathrm{R}_{\mathrm{i}, \mathrm{t}}\right]=$ return ekspektasian sekuritas ke-i untuk periode peristiwa ke-t

Cumulative abnormal return merupakan penjumlahan return tak normal hari sebelumnya di dalam periode peristiwa untuk masing-masing sekuritas. Penelitian ini menggunakan metode periode pendek (short event window) selama 6 hari yang terdiri dari 3 hari sebelum Pelantikan Presiden dan Wakil Presiden Indonesia Tahun 2019 dilaksanakan (t-3), 1 hari saat pelaksanaan Pelantikan Presiden dan Wakil Presiden Indonesia 2019 (t0), dan 3 hari sesudah Pelantikan Presiden dan Wakil Presiden Indonesia 2019 dilaksanakan $(t+3)$. Peneliti menilai dengan menggunakan 6 hari merupakan jumlah yang tepat untuk mengetahui respon dari para investor atas kejadian pengumuman suatu peristiwa. Tanggal peristiwa (event date) pada penelitian ini adalah pada tanggal 20 Oktober 2019. Oleh karena itu, penelitian ini menetapkan tanggal peristiwa pada tanggal 20 Oktober 2019.

Metode pengumpulan data yang digunakan dalam penelitian ini adalah metode observasi non partisipan, yaitu metode pengumpulan data dengan observasi atau pengamatan dimana peneliti tidak terlibat secara langsung dan 
hanya sebagai pengamat independen (Sugiyono, 2014). Penelitian ini menggunakan data yang diperoleh melalui pengamatan dan mencatat dengan mengakses situs Bursa Efek Indonesia melalui www.idx.co.id dan situs penyedia berita keuangan, data dan penawaran saham finance.yahoo.com.

Populasi dalam penelitian ini adalah saham-saham yang terdaftar dalam indeks saham LQ45 di Bursa Efek Indonesia. Alasan menggunakan saham-saham perusahaan yang tergolong indeks LQ45, karena sahamnya memiliki karakteristik dengan tingkat likuiditas tinggi sehingga mudah untuk diperdagangkan dan memiliki kapitalisasi pasar di BEI yang relatif besar. Oleh karena itu pemilihan saham yang tergolong LQ45 ini memberikan gambaran yang akurat akan perubahan nilai pasar dari seluruh saham yang aktif diperdagangkan di (Fakhruddin \& Hadianto, 2001:203). Oleh sebab itu, dengan menggunakan saham yang tergolong ke dalam Indeks LQ45 diharapkan dapat mewakili pasar dan dapat memperoleh hasil yang mencerminkan reaksi pasar modal Indonesia secara menyeluruh dan lebih akurat terhadap peristiwa pelantikan presiden dan wakil presiden negara Indonesia tahun 2019.

Metode penentuan sampel yang digunakan adalah metode nonprobability sampling dengan menggunakan teknik purposive sampling. Purposive sampling adalah metode penentuan sampel dengan pertimbangan-pertimbangan tertentu sehingga sampel yang dibentuk dapat mewakili sifat-sifat populasi.

Teknik analisis dalam penelitian ini menggunakan paired sample t-test, yaitu metode uji paired sample t-test selama 6 hari periode peristiwa. Kriteria uji paired samples t-test ini adalah apabila nilai asymp. Sig. (2 tailed) < tingkat keyakinan $\mathrm{a}=5 \%(0,05)$, maka $\mathrm{H}_{1}$ diterima, sebaliknya apabila asymp. Sig. (2-tailed) > 0,05 maka $\mathrm{H}_{1}$ ditolak. Uji tersebut sering digunakan ketika menguji model analisis data sebelum dan sesudah. Tujuan pengujian dengan paired sample t-test yaitu untuk memperlihatkan apakah terdapat abnormal return yang signifikan di sekitar peristiwa pemilihan presiden Indonesia 2019 yaitu sebelum dan sesudah peristiwa. Signifikansi yang dimaksud yaitu bahwa abnormal return tersebut secara statistik signifikan tidak sama dengan nol (positif untuk kabar baik dan negatif untuk kabar buruk) (Tandelilin, 2010). Pengujian analisis dalam penelitian ini menggunakan software Microsoft Excel dan SPSS versi 23.

\section{HASIL DAN PEMBAHASAN}

Hasil analisis statistik deskriptif yang akan diuji untuk variabel penelitian cumulative abnormal return (CAR) berjumlah 45 sampel perusahaan. Hasil analisis statistik deskriptif sampel penelitian disajikan sebagai berikut:

Tabel 1. Statistik Deskriptif Cumulative Abnormal Return Sebelum dan Sesudah Peristiwa

\begin{tabular}{cccccc}
\hline Variabel & Jumlah & Minimum & Maksimum & Rata-Rata & $\begin{array}{c}\text { Std. } \\
\text { Deviation }\end{array}$ \\
\hline CAR Sebelum & 45 & $-90,000$ & 147,000 & $-6,820$ & 45,700 \\
CAR Sesudah & 45 & $-76,000$ & 86,000 & $-0,400$ & 33,878 \\
\hline
\end{tabular}

Sumber: Data Penelitian, 2020

Tabel 1, menjelaskan nilai minimum, maksimum, rata-rata, dan standar deviasi sebelum dan sesudah peristiwa pelemahan nilai rupiah pada nilai tukar US Dollar. Berdasarkan tabel 1, nilai cumulative abnormal return (CAR) sebelum 
peristiwa menunjukkan rata-rata sebesar $-6,820$ dengan standar deviasi sebesar 45,700. Nilai tersebut memiliki rata-rata negatif, hal ini berarti bahwa 3 hari sebelum peristiwa investor cenderung memiliki reaksi negatif dalam pembelian saham perusahaan. Nilai CAR sebelum peristiwa terendah adalah sebesar $-90,000$ dan nilai CAR sebelum peristiwa tertinggi adalah sebesar 147,000.

Nilai cumulative abnormal return (CAR) sesudah peristiwa menunjukkan rata-rata sebesar $-0,400$ dengan standar deviasi sebesar 33,878. Nilai tersebut memiliki rata-rata negatif, hal ini berarti bahwa 3 hari sesudah peristiwa investor cenderung memiliki reaksi negatif dalam pembelian saham perusahaan. Nilai CAR sesudah peristiwa terendah adalah sebesar $-76,000$ dan nilai CAR sesudah peristiwa tertinggi adalah sebesar 86,000 .

Hasil analisis statistik deskriptif yang akan diuji untuk variabel penelitian cumulative abnormal return (CAR) berjumlah 45 sampel perusahaan. Hasil analisis statistik deskriptif sampel penelitian disajikan sebagai berikut:

Tabel 2. Statistik Deskriptif Cumulative Abnormal Return Sebelum dan Sesudah Peristiwa

\begin{tabular}{llllll}
\hline Variabel & Jumlah & Minimum & Maksimum & Rata-Rata & $\begin{array}{l}\text { Std. } \\
\text { Deviation }\end{array}$ \\
\hline CAR Sebelum & 45 & $-90,000$ & 147,000 & $-6,820$ & 45,700 \\
CAR Sesudah & 45 & $-76,000$ & 86,000 & & $-33,878$ \\
& & & & 0,400 & \\
\hline
\end{tabular}

Sumber: Data Penelitian, 2020

Tabel 2, menjelaskan nilai minimum, maksimum, rata-rata, dan standar deviasi sebelum dan sesudah peristiwa pelemahan nilai rupiah pada nilai tukar US Dollar. Berdasarkan tabel 2, nilai cumulative abnormal return (CAR) sebelum peristiwa menunjukkan rata-rata sebesar $-6,820$ dengan standar deviasi sebesar 45,700 . Nilai tersebut memiliki rata-rata negatif, hal ini berarti bahwa 3 hari sebelum peristiwa investor cenderung memiliki reaksi negatif dalam pembelian saham perusahaan. Nilai CAR sebelum peristiwa terendah adalah sebesar -90,000 dan nilai CAR sebelum peristiwa tertinggi adalah sebesar 147,000.

Nilai cumulative abnormal return (CAR) sesudah peristiwa menunjukkan rata-rata sebesar $-0,400$ dengan standar deviasi sebesar 33,878. Nilai tersebut memiliki rata-rata negatif, hal ini berarti bahwa 3 hari sesudah peristiwa investor cenderung memiliki reaksi negatif dalam pembelian saham perusahaan. Nilai CAR sesudah peristiwa terendah adalah sebesar $-76,000$ dan nilai CAR sesudah peristiwa tertinggi adalah sebesar 86,000.

Uji normalitas yang digunakan dalam penelitian ini adalah uji kolmogorovsmirnov dengan tingkat kepercayaan $95 \%$ atau $\alpha=5 \%$. Hasil uji normalitas dalam penelitian ini disajikan sebagai berikut.

Tabel 3. Pengujian Normalitas Cumulative Abnormal Return Sebelum dan Sesudah Peristiwa

\begin{tabular}{llcll}
\hline Variabel & Jumlah & Sig (2-Tailed) & Kriteria & Keterangan \\
\hline CAR Sebelum & 45 & 0,200 & 0,05 & Berdistribusi \\
& & & & Normal \\
CAR Sesudah & 45 & 0,200 & 0,05 & $\begin{array}{l}\text { Berdistribusi } \\
\text { Normal }\end{array}$ \\
\hline
\end{tabular}

Sumber: Data Penelitian, 2020 
Berdasarkan tabel 3, nilai signifikansi K-S variabel cumulative abnormal return (CAR) sebelum peristiwa adalah sebesar 0,200 dan sesudah peristiwa adalah sebesar 0,200 yang nilainya diatas kriteria 0,05 maka berarti variabel CAR sebelum dan sesudah peristiwa berdistribusi normal sehingga pengujian hipotesis selanjutnya dengan menggunakan statistik parametrik, yaitu paired sample t-test.

Pengujian hipotesis ini dilakukan dengan menggunakan uji paired sample ttest. Hipotesis menguji apakah terdapat perbedaan rata-rata abnormal return sebelum dan sesudah peristiwa pelantikan presiden dan wakil presiden tanggal 20 Oktober 2019. Hasil uji paired sample t-test disajikan sebagai berikut.

Tabel 4. Hasil Uji Paired Sample T-Test Abnormal Return Sebelum dan Sesudah Peristiwa

\begin{tabular}{llclll}
\hline Variabel & Jumlah & t-hitung & Sig (2-Tailed) & Kriteria & Keterangan \\
\hline $\begin{array}{l}\text { AAR Sebelum- } \\
\text { Sesudah }\end{array}$ & 45 & $-0,733$ & 0,468 & 0,05 & Tidak \\
Signifikan \\
\hline
\end{tabular}

Sumber: Data Penelitian, 2020

Berdasarkan Tabel 4, abnormal return sebelum dan sesudah peristiwa menunjukkan nilai signifikansi sebesar 0,468. Nilai signifikansi dibawah 0,05 menunjukkan bahwa adanya perbedaan yang signifikan. Sehingga dapat disimpulkan bahwa hipotesis ditolak, hal ini berarti tidak terdapat perbedaan abnormal return sebelum dan sesudah peristiwa pelantikan presiden dan wakil presiden tahun 2019 atau dengan kata lain peristiwa pelantikan presiden dan wakil presiden Indonesia tahun 2019 tidak memiliki kandungan informasi.

Penelitian dengan menggunakan event study dan teori efisiensi pasar pada peristiwa pelantikan presiden dan wakil presiden Indonesia tahun 2019 menunjukkan bahwa peristiwa ini tidak memiliki kandungan informasi yang menyebabkan pelaku pasar tidak bereaksi terhadap peristiwa tersebut. Hasil pengujian menunjukkan tidak terdapat perbedaan cummulative abnormal return sebelum dan sesudah peristiwa pelantikan presiden dan wakil presiden Indonesia tahun 2019 pada tanggal 20 Oktober 2019.

Hasil uji paired sample t-test menunjukkan nilai CAR sebelum dan sesudah peristiwa menunjukkan nilai rata-rata $-6,422$ nilai $t$ sebesar $-0,733$ dan nilai signifikansi sebesar 0,468. maka dapat disimpulkan H0 diterima dan H1 ditolak karena nilai signifikan lebih besar dari 0,05. Hasil ini diperkuat dengan Penelitian Oka (2015) menunjukkan bahwa tidak terdapat perbedaan rata-rata abnormal return sebelum dan sesudah peristiwa Pilpres Indonesia 2014. Asshodiqi (2016) menunjukkan bahwa tidak terdapat perbedaan rata-rata abnormal return pada uji paired sample $t$-test pada peristiwa pelantikkan presiden Indonesia tahun 2014. Nuryana (2017) menunjukkan bahwa peristiwa pengangkatan Jokowi menjadi presiden pada tahun 2014 tidak terdapat kandungan informasi, yang diperjelas dengan tidak signifikannya nilai abnormal return dan trading volume activity.

Penelitian-penelitian ini merupakan penelitian terhadap reaksi pasar atas terpilihnya Joko Widodo sebagai presiden pada tahun 2014, ketiga penelitian ini menunjukkan hasil yang sama yaitu peristiwa tidak mengandung kandungan informasi yang menyebabkan tidak adanya reaksi pasar. Pelantikan presiden Joko Widodo untuk yang kedua kalinya dianggap oleh pelaku pasar modal sebagai hal yang kurang berpengaruh terhadap pasar modal, pelaku pasar modal 
sudah mengetahui sepak terjang Joko Widodo sebagai presiden pada periode 2014-2019 yang membuat kurang tertariknya pelaku pasar modal. Pelaku pasar modal menginginkan kebijakan yang berlanjut (policy continuation) yang didapat dengan terpilihnya tim ekonomi yang bagus pada kabinet Menteri periode 20192024.

Informasi yang relevan dengan kondisi pasar modal merupakan sesuatu yang selalu dicari para pelaku pasar modal dalam upaya melakukan pengambilan keputusan investasi. Informasi yang tersebar tidak semua merupakan informasi yang berharga, akibatnya para pelaku pasar modal harus secara tepat memilah informasi-informasi yang layak (relevan) dijadikan pertimbangan pengambilan keputusan. Peristiwa pelantikan presiden dan wakil presiden Indonesia tahun 2019 menunjukkan tidak adanya reaksi yang diukur dengan abnormal return dan cummulative abnormal return sebelum dan sesudah peristiwa.

Tidak adanya reaksi pasar tersebut berarti investor tidak menggunakan informasi dari peristiwa pelantikan presiden dan wakil presiden Indonesia 2019 dalam menanggapi keputusan untuk berinvestasi. Sehingga kedepannya penting bagi investor untuk lebih mempertimbangkan informasi dari peristiwa non ekonomi di waktu mendatang.

\section{SIMPULAN}

Berdasarkan hasil pengujian dan analisis yang telah dilakukan, dapat ditarik kesimpulan bahwa selama enam hari perdagangan saham di sekitar peristiwa pelantikan presiden dan wakil presiden Indonesia tahun 2019 dengan menggunakan variabel cumulative abnormal return (CAR) pada perusahaan yang terdaftar pada indeks saham LQ45 menunjukkan bahwa tidak terdapat reaksi pasar atas peristiwa tersebut. Hasil uji paired sample t-test menghasilkan bahwa tidak terdapat reaksi pasar terhadap pelantikan presiden dan wakil presiden Indonesia tahun 2019. Hal tersebut menunjukkan bahwa peristiwa tersebut tidak memiliki kandungan informasi yang cukup bagi investor dalam mengambil keputusan investasi terhadap perusahaan-perusahaan saham LQ45 yang terdaftar di Bursa Efek Indonesia.

Investor dapat memperhatikan peristiwa-peristiwa di bidang ekonomi serta adanya kebijakan-kebijakan terkait ekonomi makro yang diprediksi dapat mempengaruhi pasar modal sehingga menjadi pertimbangan bagi investor dalam menentukan strategi perdagangan sahamnya. Bagi peneliti selanjutnya disarankan untuk meneliti peristiwa lain khususnya terkait peristiwa yang dilakukan pemerintah sehingga bisa diketahui apakah investor tertarik dengan adanya peristiwa-peristiwa yang diprediksi dapat mempengaruhi pasar modal.

\section{REFERENSI}

Ayu, I., \& Prameswari, N. (2018). E-Jurnal Akuntansi Universitas Udayana Analisis Reaksi Pasar Modal Pada Peristiwa Pemilihan Gubernur Dki Jakarta Tahun 2017 Fakultas Ekonomi dan Bisnis Universitas Udayana ( Unud), Bali, Indonesia Fakultas Ekonomi dan Bisnis Universitas Udayana (Unud ). 22, 944-975.

Fakhruddin, \& Hadianto, S. (2001). Perangkat dan Model Analisis Investasi di Pasar Modal (Buku Satu). Jakarta: Elex Media Komputindo. 
Firstiany, J. I., \& Wirama, D. G. (2019). E-Jurnal Akuntansi Universitas Udayana Reaksi Pasar Atas Right Issue Fakultas Ekonomi dan Bisnis Universitas Udayana ( Unud ), Bali, Indonesia. 27, 285-310.

Hartono, J. (2017). Teori Portofolio dan Analisis Investasi (Edisi 11). Yogyakarta: BPFE.

Napitupulu, E. A., \& Yasa, G. W. (2018). E-Jurnal Akuntansi Universitas Udayana Analisis Reaksi Pasar Terhadap Perubahan Peraturan Kemenperin Nomor 31 / M-Ind / Per / 8 / 2017 Pada Perusahaan Manufaktur di BEI Fakultas Ekonomi dan Bisnis Universitas Udayana ( Unud ), Bali , Indonesia email : gia. E-Jurnal Akuntansi Universitas Udayana, 25, 667-689.

Nuryana, I. (2017). Analisis Reaksi Pasar Modal Terhadap Pengangkatan Joko Widodo Sebagai Presiden Republik Indonesia. Referensi: Jurnal Ilmu Manajemen Dan Akuntansi, 4(2), 1. https://doi.org/10.33366/ref.v4i2.517

Pastika, I. W. A., \& Widanaputra, A. A. G. P. (2019). E-Jurnal Akuntansi Universitas Udayana Analisis Reaksi Pasar Terhadap Pengumuman Dividen Saham Fakultas Ekonomi dan Bisnis Universitas Udayana ( Unud), Bali, Indonesia. 27, 822-846.

Rao, S., \& Goldsby, T. J. (2009). Supply chain risks: A review and typology. The International Journal of Logistics Management, Vol. 20, pp. 97-123. https:// doi.org/10.1108/09574090910954864

Tandelilin, E. (2010). Portofolio dan Investasi (Pertama). Yogyakarta: Kanisius.

Utami S, C. H., Yuniarta, G. A., \& Sujana, E. (2017). Reaksi Investor dalam Pasar Modal terhadap Peristiwa Pada Nilai Tukar Rupiah ( Event Study pada Peristiwa Menguatnya Kurs Dolar AS Terhadap Nilai Tukar Rupiah Tanggal 26 Agustus 2015 ). E-Jurnal Universitas Pendidikan Ganesha, 07(01).

Wahyudhi, P. S., \& I G.N. Agung Suaryana. (2019). Reaksi Pasar Atas Kesepakatan Investasi Bidang Infrastruktur dalam Pertemuan International Monetary Fund-World Bank 2018. E-Jurnal Akuntansi Universitas Udayana, 27, 594-643.

Xiao, X., \& Gao, Y. (2017). An Event Study of The Effects of Regulatory Changes on The Food Industry. China Agricultural Economic Review, 9(1), 81-92. https:// doi.org/10.1108/CAER-01-2014-0006 